\title{
Brazil's planned exploitation of Amazonian indigenous lands for commercial agriculture increases risk of new pandemics
}

\author{
Lucas Ferrante $^{1}\left(\mathbb{D} \cdot\right.$ Reinaldo Imbrozio Barbosa $^{2} \cdot$ Luiz Duczmal $^{3} \cdot$ Philip Martin Fearnside $^{2}$
}

Received: 23 March 2021 / Accepted: 25 July 2021 / Published online: 18 August 2021

(c) The Author(s), under exclusive licence to Springer-Verlag GmbH Germany, part of Springer Nature 2021

\begin{abstract}
We report the emergence of a new production chain for commercial food that aims to maximize profit to the detriment of the environment and traditional communities in the Amazonian region. In addition, the combination of environmental impact and the raising of confined animals (including pigs and poultry), in locations where the animals may have contact with other diseases carries the danger of generating a new pandemic of worldwide proportions.
\end{abstract}

Keywords Amazonian savanna · Brazil · Campinas · Campinaranas · Deforestation · Epidemiology · Indigenous peoples · SARS-CoV-2

We have observed that the forces driving deforestation in the Amazon have significantly increased since Jair Bolsonaro took office as Brazil's president on 1 January 2019 (Abessa et al. 2019; Ferrante and Fearnside 2019, 2020a; Vale et al. 2021). The Amazon region has been targeted for the expansion of new industrial centers, and new roads have given access to areas that were previously untouched (Ferrante and Fearnside 2019; 2020a; b). The presidential administration is trying to open indigenous lands to non-indigenous people for monoculture plantations and consolidate this sector in the Amazon region by loosening federal environmental legislation (Ferrante and Fearnside 2020c; Siqueira-Gay et al. 2020). Here, we report how these changes are linked to a new production chain for commercial food products to the detriment of the environment and traditional communities and how this increases the risk of new pandemics.

Communicated by Wolfgang Cramer

Lucas Ferrante

lucasferrante@hotmail.com

1 Programa de Pós-Graduação em Ecologia, Instituto Nacional de Pesquisas da Amazônia (INPA), Amazonas, Manaus, Brazil

2 Instituto Nacional de Pesquisas da Amazônia (INPA), Manaus, Amazonas, Brazil

3 Universidade Federal de Minas Gerais (UFMG), Belo Horizonte, Minas Gerais, Brazil
One of the companies installed in the region for this purpose is Millenium Bioenergy, which would, in principle, have its production focused only on biofuels (Ferrante and Fearnside 2020a; NovaCana 2019). However, the company has announced that it will enter into "partnerships" with indigenous communities and other local communities to produce corn, fish, chickens, and pigs and confined cattle for sale to the company (BrasilAgro 2019; NovaCana 2019; see interview with company representative: Ferrante 2020). A representative of the company who handles environmental licensing told us that the plans for this initiative in the states of Amazonas and Roraima, in the northern Brazilian Amazon (Fig. 1), would be to produce biofuels from monocultures in indigenous lands and other traditional communities (see interview with company representative: Ferrante 2020). The communities would not be paid, but the company would subsidize the establishment of a production chain for confined animals consuming feed produced by the company itself with corn stalks and other plant material discarded in the biofuel-production process. The company's advertisements (see BrasilAgro 2019) corroborate this plan for integrating indigenous people and their land into the agribusiness supply chain. According to the company representative in an official interview with us, these products would be exported through the port in Georgetown in neighboring Guyana, mainly to China and other Asian countries, but also to the USA and Europe (see interview with company representative: Ferrante 2020). 
Fig. 1 A Map with Millenium industries: (1) Bonfim; (2) Manaus; (3) Rio Preto da Eva; (4) Itacotiara. B Campinas vegetation in Rio Preto da Eva municipality. C Campinaranas vegetation in Rio Preto da Eva municipality. D Lavrado "Roraima savanna" burning. E Field of corn grown by an agribusiness company in what was once a lavrado (savanna) in Roraima, in the northern Brazilian Amazon (photos: Lucas Ferrante)
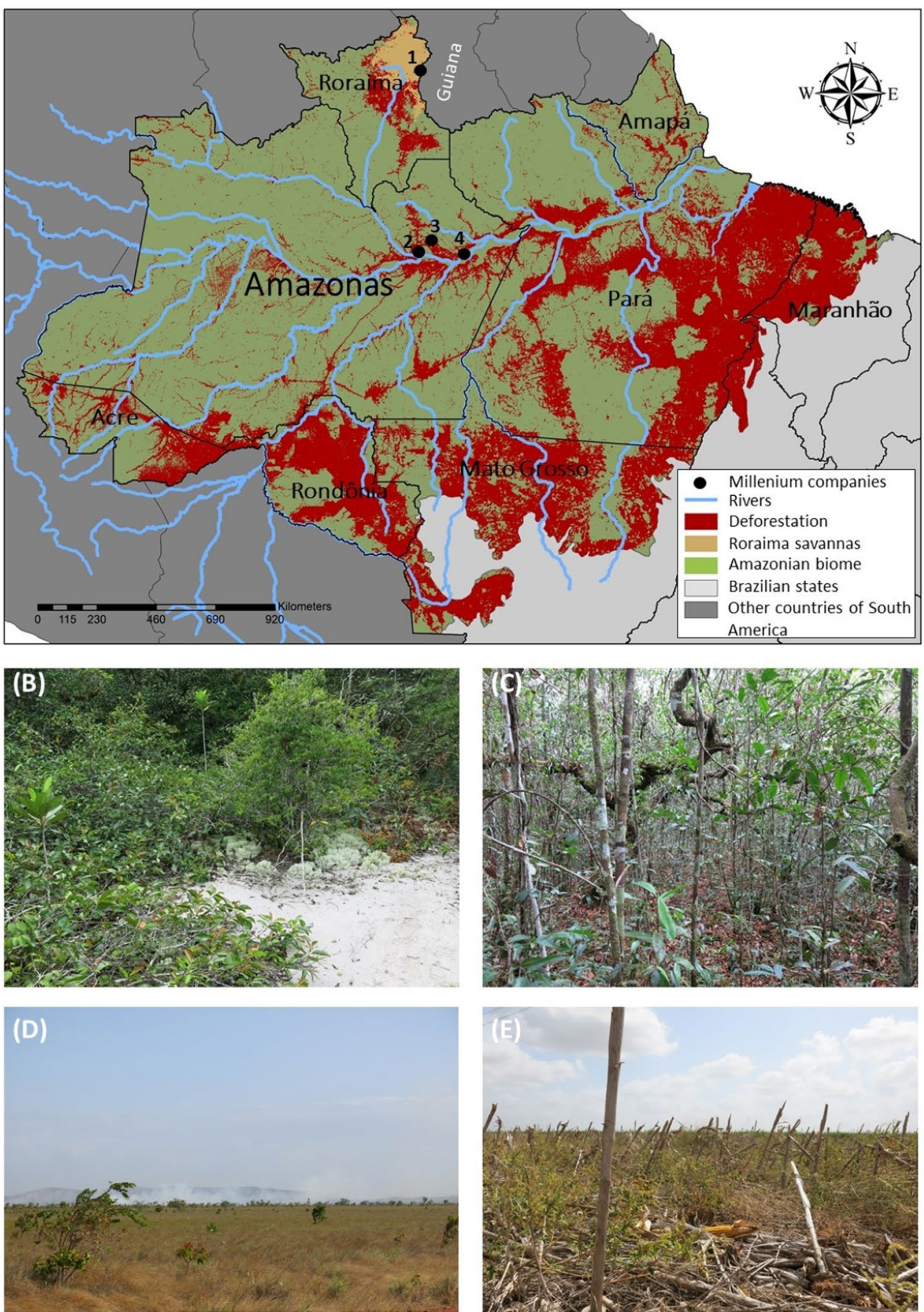

Production of monocultures in the Amazon can significantly increase deforestation and, in the case of Roraima, increase the loss of the highly biodiverse Roraima savanna or lavrado (Barbosa et al. 2007; Ferrante and Fearnside 2018). This is happening now in Roraima and is not just a future possibility. The Amazon is considered to be a possible source of the next pandemic, as deforestation provides opportunities for disease agents from the region's large reservoir of zoonoses to jump to the human population (Ellwanger et al. 2020). Raising confined animals (including pigs and poultry as proposed by Millenium Bioenergy) (BrasilAgro 2019) in locations where the domestic animals may come into contact with disease agents risks generating a new pandemic of worldwide proportions (Cohen 2020). The likelihood of containing such an outbreak is slim, as suggested by the inadequate response that the region has had to the COVID-19 pandemic (Ferrante and Fearnside 2020d; Ferrante et al. 2020; Lancet 2020).

The risk of a new pandemic is increased by the Amazon being one of the world's largest reservoirs of different 
types of coronavirus (Ramon 2020), and the possibility of contact of these viruses with SARS-CoV-2 (the virus that causes COVID-19) could result in an even-more dangerous strain emerging through recombination (Shumei and Caiyu 2021). The Amazonas State Public Ministry for Accounts (MPC/RAM) has formally requested the Agency for Agriculture, Ranching and Forestry Defense of the State of Amazonas (ADAF), for data on SARS-CoV-2 infections of cattle (Ministério Público de Contas do Estado do Amazonas 2021). In regions with a high prevalence of SARS-CoV-2 disease in humans and livestock, such as South America, close contact between farm animals and any infected humans who are tending them could cause anthropo-zoonotic infections of the livestock, as has been already described for highly susceptible animal species such as minks, felids, and dogs (Ulrich et al. 2020). Recent studies have reported that swine are also susceptible to SARS-CoV-2 infection (Pickering et al. 2021). Official sources attest to both the susceptibility of wild animals present in the region (such as bats and primates) to SARSCoV-2 and their ability to transmit the virus (Departamento de Saúde Animal 2020). This implies the possibility of zoonotic leaps, including from beta coronaviruses present in the Amazon jumping to domestic animals and from these to humans.

Allowing monoculture plantations by non-Indians on indigenous lands, as proposed by a bill submitted to Brazil's National Congress by President Jair Bolsonaro, would further heighten social inequality within the communities and increase their vulnerability (Ferrante and Fearnside 2019; Lima et al. 2020). Traditional communities that allowed their lands in eastern Amazonia to be used for producing oil palm for the food industry did not obtain sufficient income even to meet basic subsistence needs, requiring intervention by Brazil's Federal Public Ministry (a special prosecutor's office for defending the rights of the people) (Glass 2013; see also: Butler 2021).

Amazonian indigenous lands are much better preserved as compared to other protected-area types (Ferrante et al. 2021a; Nogueira et al. 2018a), and they have a significant role in maintaining global climate stability and biodiversity (Fa et al. 2020; Ferrante and Fearnside 2020a; Nepstad et al. 2006; Nogueira et al. 2018b; Walker et al. 2020). Epidemiological outbreaks in these areas represent a threat to Indigenous peoples both because these peoples are neglected by the government and because of the absence of doctors and basic medicines in the communities (Ferrante and Fearnside 2020d; Ferrante et al. 2020).

Epidemiological outbreaks have the power to decimate entire indigenous cultures, given that traditional knowledge is passed orally by elders who are the most vulnerable to these outbreaks (Ferrante et al. 2020). In the Millenium Bioenergy project in Roraima, building a hospital for the indigenous people was announced as a form of compensation (BrasilAgro 2019). This promise is not expected to be fulfilled since the company has not even honored its obligation to carry out the environmental studies that are legally required for the installation of an industry (Ministério Público de Contas do Estado do Amazonas 2020).

Expansion of monocultures and other crops would impact the natural vegetation of the area (Ferrante and Fearnside 2018, 2020a), such as campinas and campinaranas (open vegetation on white-sand soils) and the lavrado (Roraima savannas), thus threatening species endemic to these areas (Fig. 1) (Barbosa et al. 2007; Ferrante and Fearnside 2018; Oliveira et al. 2001). Pesticides applied to crops have mutagenic and lethal effects on fauna in the region (Ferrante and Fearnside 2020e). Millenium Bioenergy plans to have installations in three municipalities (counties): Rio Preto da Eva and Itacoatiara (which have the largest areas of campinas and campinaranas in the state of Amazonas) and Bonfim (which is surrounded by the lavrado in the state of Roraima) (Barbosa et al. 2007; BrasilAgro 2019; Oliveira et al. 2001). A proposed alteration of Brazil's ecological-economic zoning would allow sugarcane plantations, a legislative change that has been delayed in the National Congress but could be enacted in the future (Ferrante and Fearnside 2018).

We expect that no control of this type of activity in the Amazon region can be expected under the current political environment, where Brazilian agribusinesses and their political representatives have instigated human rights violations and promoted deforestation and use of pesticides that are banned in most countries (Ferrante and Fearnside 2020a). The government has dismantled its sanitary and environmental-control agencies and has gutted actions intended to curb deforestation (Ferrante and Fearnside 2019; 2020f; Gonzales 2020; Silva Junior et al. 2020) and repress environmental crimes by invaders in indigenous areas (Ferrante and Fearnside 2020c; HRW (Human Rights Watch) 2019). These risks are likely to increase further because bills have been recently submitted to the National Congress by Brazil's President that would further weaken protections of the environment and indigenous lands and likely intensify rural conflicts (including attacks on indigenous peoples) by relaxing gun controls (Ferrante and Fearnside 2021). Given this scenario, there are no guarantees that the commercial food products of new business initiatives in traditional communities are not linked to deforestation, to the emergence of new diseases, to the spread of diseases from non-indigenous to indigenous people (Walker et al. 2015), and to the violation of human rights (such as "slave" labor), or that the foodstuffs that are exported meet international sanitary standards.

On 21 February 2021, the heads of IBAMA (Brazil's agency responsible for environmental protection and inspection) and FUNAI (the agency created to protect indigenous peoples) published a joint normative instruction 
$(08,620.001464 / 2021-81)$ that removes the prohibition of monoculture plantations in Indigenous lands (Diário Oficial da União 2021). Opening Indigenous lands to agribusiness is part of the anti-environmental agenda of Brazil's current presidential administration (Ferrante and Fearnside 2019; Torres and Branford 2020). In addition to their social impacts, monocultures cause habitat loss and fragmentation by replacing natural ecosystems. They impact forest areas adjacent to the plantations through edge effects, including loss of amphibians, and other insect predators that help control disease vectors (Ferrante et al. 2017). The federal government also plans to open conservation units in the Amazon for cattle raising (Ferrante and Fearnside 2019). In addition to forest degradation and loss of biodiversity (Ferrante et al. 2017), this would also increase the risk of anthropo-zoonotic infections and of epidemics (Ulrich et al. 2020).

The risk of a new pandemic cannot be ignored. Federal, state, and municipal (county) authorities have ignored warnings of a worsening COVID-19 pandemic in the Amazon, such as the risk of emergence of more virulent and vaccine-resistant coronavirus variants (Ferrante et al. 2021b). Warnings like the present one of the increased danger of pandemics from installing this production chain are often unheeded: there was a warning of the COVID-19 pandemic a year before it emerged, with the identification of coronaviruses in bats in the Wuhan region of China (Fan et al. 2019). A new global public health crisis arising in the Amazon is potentially more significant than the one that occurred in Wuhan. This is because the Amazon is one of the world's largest reservoirs of zoonoses (Ellwanger et al. 2020). The precarious healthcare available in the Amazonian interior, especially for peoples (Ferrante and Fearnside 2020d; Rocha 2020), means that we would expect any efforts to contain a newly emerged disease to be long delayed and ineffective. The state governments in Brazil's portion of the region have failed to take the necessary efforts to contain the present COVID-19 pandemic, including the Gamma (P.1) variant that originated in the region (DW 2021). A new pandemic originating in the Amazon would likely go unnoticed until it spreads beyond the region.

It is necessary to halt the installation of this new production chain in the region, given its negative impact on traditional peoples and their territories and on biodiversity, climate, and the risk of new pandemics. We recommend the immediate revocation of the normative instruction that removed the prohibition of monoculture plantations in Indigenous lands (No. 08620.001464/2021-81). We also recommended that cattle raising remain prohibited in conservation units (protected areas for biodiversity).

The international context of events in Amazonia is changing, with countries such as the USA and China now considering the reduction of tropical deforestation to be a priority due to concerns about anthropogenic climate change and the emergence of new pandemics. This changing context could have a direct impact on the implementation of the new production chain discussed here. We recommend boycotts of companies linked to this production chain, both by purchasers and by providers of financing. Countries that are part of international climate and biodiversity conventions must consider these companies as potentially harmful to the objectives of these agreements.

Acknowledgements PMF thanks Conselho Nacional de Desenvolvimento Científico e Tecnológico (CNPq) Proc. 311103/2015-4.

\section{References}

Abessa D, Famá A, Buruaem L (2019) The systematic dismantling of Brazilian environmental laws risks losses on all fronts. Nat Ecol Evol 3:510-511. https://doi.org/10.1038/s41559-019-0855-9

Barbosa RI, Campos C, Pinto F, Fearnside PM (2007) The "lavrados" of Roraima: biodiversity and conservation of Brazil's Amazonian savannas. Funct Ecos Commun 1:30-42. https://bityl.co/5J9w

BrasilAgro (2019) Millenium Bioenergy vai produzir etanol a partir do milho no Amazonas. https://bityl.co/5J91

Butler RA (2021) Amazon palm oil has not lived up to its promise of sustainability (commentary). Mongabay, 20 May 2021. https:// bityl.co/6xVD

Cohen J (2020) Swine flu strain with human pandemic potential increasingly found in pigs in China. Science abd5761. https:// doi.org/10.1126/science.abd5761

Departamento de Saúde Animal (2020) SARS-CoV-2 em Animais. Departamento de Saúde Animal, Campo Grande, MS, Brazil. https://www.iagro.ms.gov.br/wp-content/uploads/2020/12/Ficha 13007022_Ficha_Tecnica_SARS_CoV_2_animais_nov2020.pdf

Diário Oficial da União (2021) Instrução normativa conjunta $\mathrm{N}^{\circ} 1$, de 22 de fevereiro de 2021. https://tinyurl.com/mdcwca2

DW (2021) Japão identifica nova variante do coronavírus em viajantes do Brasil. https://bityl.co/5AuZ

Ellwanger JH, Kulmann-Leal B, Kaminski VL, Valverde-Villegas JM, da Veiga ABG et al (2020) Beyond diversity loss and climate change: impacts of Amazon deforestation on infectious diseases and public health. An Acad Bras Ciênc 92:art.e20191375. https:// doi.org/10.1590/0001-3765202020191375

Fa JE, Watson JEM, Leiper I, Potapov P, Evans TD et al (2020) Importance of Indigenous peoples' lands for the conservation of intact forest landscapes. Front Ecol Environ 18(3):135-140. https://doi. org/10.1002/fee. 2148

Fan Y, Zhao K, Shi Z-L, Zhou P (2019) Bat Coronaviruses in China. Viruses 11:210. https://doi.org/10.3390/v11030210

Ferrante L, Fearnside PM (2018) Amazon sugar cane: a threat to the forest. Science 359:1476. https://doi.org/10.1126/Science.aat4208

Ferrante L, Fearnside PM (2019) Brazil's new president and "ruralists" threaten Amazonia's environment, traditional peoples and the global climate. Environ Conserv 46:261-263. https://doi.org/ $10.1017 / \mathrm{S} 0376892919000213$

Ferrante L (2020) Interview with representative of environmental licensing for the Millenium project in Amazonas and Roraima. https://bityl.co/5rTG

Ferrante L, Fearnside PM (2020a) The Amazon: biofuels plan will drive deforestation. Nature 577:170. https://www.nature.com/artic les/d41586-020-00005-8 
Ferrante L, Fearnside PM (2020b) The Amazon's road to deforestation. Science 369: 634. https://science.sciencemag.org/content/ 369/6504/634.1

Ferrante L, Fearnside PM (2020c) Brazil threatens Indigenous lands. Science 368:481-482. https://doi.org/10.1126/science.abb6327

Ferrante L, Fearnside PM (2020d) Protect Indigenous peoples from COVID-19. Science 368:251. https://doi.org/10.1126/science. abc0073

Ferrante L, Fearnside PM (2020e) Evidence of mutagenic and lethal effects of herbicides on Amazonian frogs. Act Amaz 50:363-366. https://doi.org/10.1590/1809-4392202000562

Ferrante L, Fearnside PM (2020f) Military forces and COVID-19 as smokescreens for Amazon destruction and violation of indigenous rights. Erde 151:258-263

Ferrante L, Fearnside PM (2021) Brazil's political upset threatens Amazonia. Science 371:898-899. https://science.sciencemag. org/content/371/6532/898

Ferrante L, Baccaro FB, Ferreira EB, Sampaio MFO, Santos T et al (2017) The matrix effect: how agricultural matrices shape forest fragment structure and amphibian composition. J Biog 44:19111922. https://doi.org/10.1111/jbi.12951

Ferrante L, Steinmetz WA, Almeida ACL, Leão J, Vassão RC et al (2020) Brazil's policies condemn Amazonia to a second wave of COVID-19. Nat Med 26:1315. https://doi.org/10.1038/ s41591-020-1026-x

Ferrante L, Andrade MBT, Fearnside PM (2021a) Land grabbing on Brazil's Highway BR-319 as a spearhead for Amazonian deforestation. Land Use Pol 108:art. 105559. https://doi.org/10.1016/j. landusepol.2021.105559

Ferrante L, Steinmetz WA, Almeida ACL, Leão J, Tupinambás U et al (2021b) Nota técnica: Necessidade de lockdown e vacinação abrangente em Manaus para contenção da pandemia da COVID19. Instituto Nacional de Pesquisas da Amazônia (INPA), Manaus. 3 pp. https://bityl.co/5arD

Glass V (2013) Expansão do dendê na Amazônia brasileira: Elementos para uma análise dos impactos sobre a agricultura familiar no nordeste do Pará. Repórter Brasil, São Paulo, SP, Brazil. 15 pp. https://reporterbrasil.org.br/documentos/Dende2013.pdf

Gonzales J (2020) Brazil dismantles environmental laws via huge surge in executive acts: study. Mongabay, 5 August 2020. https://news. mongabay.com/2020/08/brazil-end-runs-environmental-laws-viahuge-surge-in-executive-acts-study/

HRW (Human Rights Watch) (2019) Rainforest mafias: how violence and impunity fuel deforestation in Brazil's Amazon. New York: HRW. 163 pp. https://bityl.co/4o8O

Lancet T (2020) COVID-19 in Brazil: "so what?" The Lancet 395:1461. https://doi.org/10.1016/S0140-6736(20)31095-3

Lima MG, Vale JCE, Costa GM, Santos RC, Correia Filho WLF et al (2020) The forests in the indigenous lands in Brazil in peril. Land Use Pol 90:104258. https://doi.org/10.1016/j.landusepol.2019. 104258

Ministério Público de Contas do Estado do Amazonas (2020) Rep-

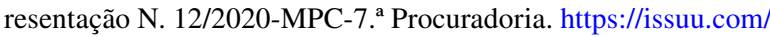
amazonasatual/docs/representacao-12-2020

Ministério Público de Contas do Estado do Amazonas (2021) $7^{\text {a }}$ Procuradoria de Contas. Ofício n. 95/2021/MPC/RMAM de 10 February 2021. https://bityl.co/5lnw

Nepstad D, Schwartzman S, Bamberger B, Santilli M, Ray D et al (2006) Inhibition of Amazon deforestation and fire by parks and indigenous lands. Conserv Biol 20(1):65-73. https://doi.org/10. 1111/j.1523-1739.2006.00351.x

Nogueira EM, Yanai AM, Vasconcelos SS, Graça PMLA, Fearnside PM (2018a) Carbon stocks and losses to deforestation in protected areas in Brazilian Amazonia. Reg Environ Change 18(1):261-270. https://doi.org/10.1007/s10113-017-1198-1

Nogueira EM, Yanai AM, Vasconcelos SS, Graça PMLA, Fearnside PM (2018b) Brazil's Amazonian protected areas as a bulwark against regional climate change. Reg Environ Change 18(2):573579. https://doi.org/10.1007/s10113-017-1209-2

NovaCana (2019) Usina de etanol de milho da Millenium Bioenergy em Roraima já pode sair do papel. https://bityl.co/5J9a

Oliveira AA, Daly DC, Vicentini A, Cohn-Haft M (2001) Florestas sobre Areia: Campinaranas e Igapós. In: Oliveira AA, Daly DC (Eds.). As florestas do Rio Negro. 1ed. São Paulo: Companhia das Letras, 179-219

Pickering BS, Smith G, Pinette MM, Embury-Hyatt C, Moffat E et al (2021) Susceptibility of domestic swine to experimental infection with severe acute respiratory syndrome coronavirus 2 . Emerg Infect Dis 27:104-112

Ramon P (2020) The Amazon could easily be the next source of coronaviruses, scientist warns. Science Alert. https://www.scienceale rt.com/amazon-could-be-next-virus-hot-zone-scientist

Rocha J (2020) Bolsonaro sends Congress bill to open indigenous lands to mining, fossil fuels. Mongabay, 7 February 2020. https://news. mongabay.com/2020/02/bolsonaro-sends-congress-bill-to-openindigenous-lands-to-mining-fossil-fuels/

Shumei L, Caiyu L (2021). Virus more dangerous if SARS-CoV-2 merges with other coronavirus: expert. Global Times. https:// www.globaltimes.cn/page/202102/1215860.shtml

Silva Junior CHL, Pessôa ACM, Carvalho NS, Reis JBC, Anderson LO et al (2020) The Brazilian Amazon deforestation rate in 2020 is the greatest of the decade. Nat Ecol Evol 5:144-145. https://doi. org/10.1038/s41559-020-01368-x

Siqueira-Gay J, Soares-Filho B, Sánchez LE, Oviedo A, Sonter LJ (2020) Proposed legislation to mine Brazil's Indigenous lands will threaten Amazon forests and their valuable ecosystem services. One Earth 3:1-7. https://doi.org/10.1016/j.oneear.2020.08.008

Torres M, Branford S (2020) Brazil opens 38,000 square miles of indigenous lands to outsiders. Mongabay, 8 May 2020. https:// news.mongabay.com/2020/05/brazil-opens-38000-square-milesof-indigenous-lands-to-outsiders/

Ulrich L, Wernike K, Hoffmann D, Mettenleiter TC, Beer M (2020) Experimental infection of cattle with SARS-CoV-2. Emerg Infect Dis 26:2979-2981. https://wwwnc.cdc.gov/eid/article/26/12/203799_article

Vale MM, Berenguer E, de Menezes MA, de Castro EBV, de Siqueira LP et al (2021) The COVID-19 pandemic as an opportunity to weaken environmental protection in Brazil. Biol Conserv 255:108994. https://doi.org/10.1016/j.biocon.2021.108994

Walker WS, Sattenspiel L, Hill KR (2015) Mortality from contactrelated epidemics among indigenous populations in Greater Amazonia. Sci Rep 5:art. 14032. https://doi.org/10.1038/srep14032

Walker WS, Gorelik SR, Baccini A, Aragon-Osejo JL, Josse C et al (2020) The role of forest conversion, degradation, and disturbance in the carbon dynamics of Amazon Indigenous territories and protected areas. Proc Nat Acad Sci USA 117(6):3015-3025. https:// doi.org/10.1073/pnas.1913321117

Publisher's Note Springer Nature remains neutral with regard to jurisdictional claims in published maps and institutional affiliations. 